\title{
Additional Information for E-Area Vault Performance Assessment, Appendix I "Suspect Soil Performance" - Results of Modeling the Effects of Organic Matter on the Mobility of Radionuclides as it Relates to the Disposal of Wood Products in E-Area Slit Trenches
}

by

S. M. Serkiz

Westinghouse Savannah River Company

Savannah River Site

Aiken, South Carolina 29808

J. L. Myers

This paper was prepared in connection with work done under the above contract number with the U.S. Department of Energy. By acceptance of this paper, the publisher and/or recipient acknowledges the U. S. Government's right to retain a nonexclusive, royalty-free license in and to any copyright covering this paper, along with the right to reproduce and to authorize others to reproduce all or part of the copyrighted paper. 


\section{DISCLAIMER}

This report was prepared as an account of work sponsored by an agency of the United States Government. Neither the United States Government nor any agency thereof, nor any of their employees, makes any warranty, express or implied, or assumes any legal liability or responsibility for the accuracy, completeness, or usefulness of any information, apparatus, product, or process disclosed, or represents that its use would not infringe privately owned rights. Reference herein to any specific commercial product, process, or service by trade name, trademark, manufacturer, or otherwise does not necessarily constitute or imply its endorsement, recommendation, or favoring by the United States Government or any agency thereof. The views and opinions of authors expressed herein do not necessarily state or reflect those of the United States Government or any agency thereof.

This report has been reproduced directly from the best available copy.

Available to DOE and DOE contractors from the Office of Scientific and Technical Information, P. O. Box 62, Oak Ridge, TN 37831; prices available from (423) 576-8401.

Available to the public from the National Technical Information Service, U. S. Department of Commerce, 5285 Port Royal Road, Springfield, VA 22161. 


\section{DISCLAIMER}

Portions of this document may be illegible electronic image products. Images are produced from the best available original document. 
WESTINGHOUSE SAVANNAH RIVER COMPANY

SAVANNAH RIVER TECHNOLOGY CENTER

\begin{abstract}
Re: Additional Information for E-Area Vault Performance Assessment, Appendix I "Suspect Soil Performance Analysis" Results of Modeling The Effects of Organic Matter on the Mobility of Radionuclides as it Relates to the Disposal of Wood Products in E-Area Slit Trenches (U)
\end{abstract}

Westinghouse $\begin{gathered}\text { S. M. Serkiz, } \\ \text { Savannah River }\end{gathered}$ Company
Savannah River Technology
$\begin{gathered}\text { Center, } \\ \text { Aiken, SC } 29808\end{gathered}$

Prepared for: Westinghouse Savannah River Company, High-Level Waste Engineering,

Savannah River Site, Aiken, SC 29808

\author{
Revision: 0 \\ Date: April 24, 1996
}




\section{WESTINGHOUSE SAVANNAH RIVER COMPANY INTER-OFFICE MEMORANDUM}

\section{SAVANNAH RIVER TECHNOLOGY CENTER INTERIM WASTE TECHNOLOGY GROUP}

SRTC-WED-96-0195

24 April 1996

TO: Don Sink, 724-9E

CC: B. Tom Butcher, 773-43A

James Cook, 773-43A

J. Steven Bellamy, 707-F

Paul Hunt, 724-15E

Winston Smith, 704-P

FROM: James L. Myers, 773A Room $02439 \mathscr{2 M}$

Steven M. Serkiz, 773-43A Room 212 sms

Re: Additional Information for E-Area Vault Performance Assessment, Appendix I "Suspect Soil Performance Analysis" - Results Of Modeling The Effects Of Organic Matter On The Mobility Of Radionuclides As It Relates To The Disposal Of Wood Products In E-Area Slit Trenches $(U)$

\section{Summary}

Numerous laboratory and field studies have shown that the chemical form (i.e., speciation) of many metals and radionuclides is affected by the presence of naturally occurring organic matter $(\mathrm{OM})$ and its degradation products. The effects of $\mathrm{OM}$ (e.g., wood products) on the speciation and, therefore, the mobility of $\mathrm{Am}, \mathrm{Bk}, \mathrm{Cf}, \mathrm{Cm}, \mathrm{Cs}, \mathrm{Ni}, \mathrm{NpO}_{2}, \mathrm{Pd}, \mathrm{PuO}_{2}$, $\mathrm{Rb}, \mathrm{Sr}, \mathrm{UO}_{2}$ and $\mathrm{Zr}$ were estimated through use of geochemical and groundwater flow modeling. Due to the complex mixture nature of naturally occurring $\mathrm{OM}$, the $\mathrm{OM}$ system was simplified through use of surrogate compounds (citric acid and ethylenedinitrilotetraacetic acid (EDTA)) to estimate effects of OM on radionuclide mobility. Using this approach, $\mathrm{OM}$ was found to have no effect on the inventory limits for $\mathrm{Cs}, \mathrm{NpO}_{2}, \mathrm{Rb}$ and $\mathrm{Zr}$. The inventory limits for the isotopes of $\mathrm{Am}, \mathrm{Bk}, \mathrm{Cf}, \mathrm{Cm}, \mathrm{Ni}, \mathrm{Pd}$, $\mathrm{PuO}_{2}, \mathrm{Sr}$, and $\mathrm{UO}_{2}$ calculated in the presence of OM decreased over a range of $26 \%$ for U-233 to $48 \%$ for Pu-240. The information in this report will be included in the next revision of the E-Area Vaults Performance Assessment. 
Geochemical modeling was used in conjunction with transport codes to estimate adjusted inventories for the E-Area slit trenches when wood products are present (see Table 1).

\section{Introduction}

Cellulosic material (e.g., wood products) and creosote (a wood preservative used to treat railroad ties) readily degrade in the environment to form organic matter (OM) in both the solid and dissolved (i.e., dissolved organic matter (DOM)) phases. The effects of OM on the speciation and mobility of inorganic elements are well documented in the open literature (Perdue and Gjessing, 1990; Thurman, 1985; Stumm and Morgan, 1981).

The disposal and degradation of wood products and creosote in the E-Area slit trenches are a source of OM. The dissolved fraction of this OM can form complexes with radionuclides, preventing them from sorbing to soil surfaces, and increasing their mobility in the soil and groundwater. This activity was undertaken to estimate the effects of the disposal of wood products on the inventory limits of various radionuclides in the E-Area slit trenches. This modeling effort consisted of coupling several well-established geochemical and groundwater flow models to estimate the effects of organic matter (OM) on the mobility of radionuclides in groundwater migrating away from the source area.

The Radiological Performance Assessment for the E-Area Vaults Disposal Facility (MMES, 1994) includes inventory limits for 29 elements (56 isotopes). The intruder pathway was identified as the only limiting pathway for 11 of these elements. Changes in the speciation of radionuclides due to the presence of OM would not reduce the inventory limits for elements in the intruder pathway. Therefore, the following 11 elements and their associated isotopes will not be considered as part of this modeling activity.

$$
\mathrm{Al}, \mathrm{Cd}, \mathrm{Co}, \mathrm{Eu}, \mathrm{Nb}, \mathrm{Pa}, \mathrm{Pb}, \mathrm{Ra}, \mathrm{Sm}, \mathrm{Sn}, \mathrm{Th}
$$

In addition, five elements ( $\mathrm{C}, \mathrm{H}, \mathrm{I}, \mathrm{Se}$, and $\mathrm{Tc})$ are identified as having a groundwater limiting pathway, but are not expected to show any effects due to-the addition of OM. These elements will not be carried forward.

The remainder of the discussion in this report will focus on the isotopes of following 13 elements, which have been identified as having a groundwater limiting pathway and have been shown to interact with naturally occurring $\mathrm{OM}$.

$$
\text { Am, Bk, Cf, Cm, Cs, Ni, Np, Pd, Pu, Rb, Sr, U, Zr }
$$




\section{Methodology}

Because of the complexities of in modeling naturally occurring OM (a complex mixture of compounds), it was necessary to simplify this problem through use of the following conceptual approach.

1. Development of a base case scenario with no OM present, using parameters typical of the subsurface environment at the SRS site for the various radionuclides reported in MMES (1994).

2. Addition of OM to the base case, using citric acid, and EDTA when citric acid stability constants were unavailable, as a surrogate for dissolved organic matter (DOM). The conservative assumption that all OM was present as DOM and available for reactions, was applied to this stage.

3. Development of a simple flow/box model to account for losses of OM from the system due to dilution, sorption, and degradation.

4. Calculation of new $\mathrm{K}_{d}$ values for the system using a weighted average approach. These calculations were based on the OM results from the flow/box modeling and equilibrium concentrations from geochemical speciation modeling of a system containing $\mathrm{OM}$.

\section{Base Case Modeling}

In order to more accurately model the subsurface geochemistry in the vicinity of E- Area slit trenches, a base case modeling scenario was developed using the following assumptions and information.

$\mathrm{pH}$

All modeling runs were conducted over a $\mathrm{pH}$ range of $4.5-6.4$. This range is typical of $\mathrm{pH}$ values in soils and groundwater at the SRS site (Strom and Kaback, 1992).

\section{Inorganic Components}

Ten elements ( $\mathrm{Am}, \mathrm{Cs}, \mathrm{Ni}, \mathrm{NpO}_{2}, \mathrm{Pd}, \mathrm{PuO}_{2}, \mathrm{Rb}, \mathrm{Sr}, \mathrm{UO}_{2}$, and $\mathrm{Zr}$ ) were considered in this analysis. These elements were selected based on their inclusion in the groundwater limiting pathway in the Radiological Performance Assessment for the E-Area Vaults Disposal Facility (MMES, 1994). The following total concentrations of components were derived using the Suspect Soil Trench Inventory Limits reported in MMES (1994), assuming a bulk soil density of $1.2 \mathrm{~g} / \mathrm{cm}^{3}$, and a soil porosity of 0.40 .
- $\mathrm{Am}^{3+}$
$2.9 \times 10^{-3} \mathrm{mg} / \mathrm{L}$ soil solution
- $\mathrm{Cs}^{+}$
$5.3 \times 10^{-5} \mathrm{mg} / \mathrm{L}$ soil solution
- $\mathrm{Ni}^{2+}$
$1.1 \mathrm{mg} / \mathrm{L}$ soil solution 
- $\mathrm{NpO}_{2}^{+}$

- $\mathrm{Pd}^{2+}$

- $\mathrm{PuO}_{2}^{2+}$

- $\mathrm{Rb}^{+}$

- $\mathrm{Sr}^{2+}$

- $\mathrm{UO}_{2}{ }^{2+}$

- $\mathrm{Zr}^{4+}$
$5.7 \times 10^{-3} \mathrm{mg} / \mathrm{L}$ soil solution

$229 \mathrm{mg} / \mathrm{L}$ soil solution

$3.27 \mathrm{mg} / \mathrm{L}$ soil solution

$1.04 \times 10^{\text {t4 }} \mathrm{mg} / \mathrm{L}$ soil solution

$7.3 \times 10^{-5} \mathrm{mg} / \mathrm{L}$ soil solution

$51.8 \mathrm{mg} / \mathrm{L}$ soil solution

$785 \mathrm{mg} / \mathrm{L}$ soil solution

The effects of adsorption of components on soil surfaces was also considered. This was modeled using distribution coefficients $\left(\mathrm{K}_{d}\right)$ reported in MMES (1994). Where:

$$
K_{a}(m L / g)=\frac{\text { soilmass }(m g / g)}{\text { aqueousmass }(m g / m L)}
$$

\section{Affects of Organic Matter on Base Case}

The affects of OM were investigated by the addition of DOM to the base modeling scenario developed above. Because of the difficulties in modeling OM (a complex mixture of compounds), it was necessary to simplify the behavior of OM through use of surrogate organic compounds. It was assumed that wood products and creosote degrade to constantly produce DOM at $30 \mathrm{mg} \mathrm{C/L}$. This DOM was then available to react with other components.

Citrate was selected as a surrogate for OM because: 1) it is a hydroxy-carboxylic acid,

- typical of cellulose degradation products (Baston et al., 1991); and 2) stability constants for reaction complexes between citrate and numerous radionuclides are available in open literature. Additionally, citrate is expected to exhibit behavior similar to acetic acid, a major product in the anaerobic degradation of creosote (Cozzarelli et al., 1994).

Therefore, citrate is believed to be a representative analogue for both wood products and creosote. A source concentration of $79 \mathrm{mg} / \mathrm{L}$ citrate $(30 \mathrm{mg} \mathrm{C} / \mathrm{L})$ was selected based on OM production from a simulated waste-form containing approximately $40 \%$ wood products (Serne et al., 1993).

Due to the lack of stability constants for reaction complexes between citrate and Pd, $\mathrm{PuO}_{2}$, and $\mathrm{Zr}$, ethylenedinitrilotetraacetic acid (EDTA) was used as a surrogate with these elements. EDTA was selected because: 1) stability constants for reaction complexes between EDTA and numerous radionuclides are available in open literature; 2 ) it is a strong complexing agent and would therefore act as a conservative surrogate for $\mathrm{OM}$. A source concentration of $69 \mathrm{mg} / \mathrm{L}$ EDTA $(30 \mathrm{mg} \mathrm{C} / \mathrm{L})$ was used.

The USEPA's metal speciation model MINTEQA2 Version 3.1 (Allison et al., 1991) was used to calculate the equilibrium concentrations of dissolved, adsorbed and solid species under various conditions. 
The thermodynamic database in the MINTEQA2 model was modified to include stability constants for $\mathrm{Am}, \mathrm{Cs}, \mathrm{Ni}, \mathrm{Pd}, \mathrm{Rb}, \mathrm{Sr}, \mathrm{UO}_{2}$ and $\mathrm{Zr}$ from Martell and Smith (1989). The stability constants for $\mathrm{NpO}_{2}$ and $\mathrm{PuO}_{2}$ were added from Rizkalla et al.(1990) and Katz et.al. (1986), respectively. The stability constants were corrected to zero ionic strength using the Davies equation.

$$
\begin{aligned}
& \mathrm{Am}^{3+}+\text { Citrate }^{3-}=\text { AmCitrate } \quad \log \mathrm{K}_{\mu=0 @ 25^{\circ} \mathrm{C}}=10.71 \\
& \mathrm{Am}^{3+}+2 \text { Citrate }^{3-}=\mathrm{Am}(\text { Citrate })_{2}{ }^{3-} \quad \log \mathrm{K}_{\mu=0 @ 25^{\circ} \mathrm{C}}=12.90 \\
& \mathrm{Am}^{3+}+\mathrm{H}^{+}+\text {Citrate }^{3-}=\text { AmHCitrate }^{+} \quad \log \mathrm{K}_{\mu=0 @ 25^{\circ} \mathrm{C}}=12.39 \\
& \mathrm{Am}^{3+}+\mathrm{H}^{+}+2 \mathrm{Citrate}^{3-}=\mathrm{AmH}(\text { Citrate })_{2}{ }^{2-} \quad \log \mathrm{K}_{\mu=0 @ 25^{\circ} \mathrm{C}}=18.64 \\
& \mathrm{Cs}^{+}+\text {Citrate }^{3-}=\text { CsCitrate }^{2-} \quad \log \mathrm{K}_{\mu=0 @ 25^{\circ} \mathrm{C}}=0.98 \\
& \mathrm{Ni}^{2+}+\text { Citrate }^{3-}=\mathrm{NiCitrate}^{-} \quad \log \mathrm{K}_{\mu=0 @ 25^{\circ} \mathrm{C}}=6.72 \\
& \mathrm{Ni}^{2+}+\mathrm{H}^{+}+\text {Citrate }^{3-}=\mathrm{NiHCitrate} \quad \log \mathrm{K}_{\mu=0 @ 25^{\circ} \mathrm{C}}=10.51 \\
& \mathrm{Ni}^{2+}+2 \mathrm{H}^{+}+\text {Citrate }^{3-}=\mathrm{NiH}_{2} \text { Citrate }^{+} \quad \log \mathrm{K}_{\mu=0 @ 25^{\circ} \mathrm{C}}=13.24 \\
& \mathrm{NpO}_{2}{ }^{+}+\text {Citrate }^{3-}=\mathrm{NpO}_{2} \text { Citrate }^{2-} \quad \log \mathrm{K}_{\mu=0 @ 25^{\circ} \mathrm{C}}=2.80 \\
& \mathrm{Pd}^{2+}+\mathrm{EDTA}^{4}=\mathrm{PdEDTA}^{2-} \quad \log \mathrm{K}_{\mu=0 @ 25^{\circ} \mathrm{C}}=20.6 \\
& \mathrm{Pd}^{2+}+\mathrm{H}^{+}+\mathrm{EDTA}^{4-}=\mathrm{PdEDTA}^{-} \quad \log \mathrm{K}_{\mu=0 @ 25^{\circ} \mathrm{C}}=24.2 \\
& \mathrm{Pd}^{2+}+2 \mathrm{H}^{+}+\mathrm{EDTA}^{4}=\mathrm{PdH}_{2} \mathrm{EDTA} \quad \log \mathrm{K}_{\mu=0 @ 25^{\circ} \mathrm{C}}=13.24 \\
& \mathrm{PuO}_{2}{ }^{2+}+\mathrm{EDTA}^{4}=\mathrm{PuO}_{2} \mathrm{EDTA}^{2-} \quad \log \mathrm{K}_{\mu=0 @ 25^{\circ} \mathrm{C}}=17.79 \\
& \mathrm{Rb}^{+}+\text {Citrate }^{3-}=\text { RbCitrate }^{2-} \quad \log \mathrm{K}_{\mu=0 @ 25^{\circ} \mathrm{C}}=1.25 \\
& \mathrm{Sr}^{2+}+\text { Citrate }^{3-}=\text { SrCitrate }^{-} \quad \log \mathrm{K}_{\mu=0 @ 25^{\circ} \mathrm{C}}=4.11 \\
& \mathrm{UO}_{2}{ }^{2+}+\text { Citrate }^{3-}=\mathrm{UO}_{2} \text { Citrate }^{-} \quad \log \mathrm{K}_{\mu=0 @ 25^{\circ} \mathrm{C}}=9.46 \\
& 2 \mathrm{UO}_{2}{ }^{2+}+2 \mathrm{Citrate}^{3-}=\left(\mathrm{UO}_{2}\right)_{2}(\text { Citrate })_{2}{ }^{2-} \quad \log \mathrm{K}_{\mu=0 @ 25^{\circ} \mathrm{C}}=21.28 \\
& \mathrm{ZR}^{4+}+\mathrm{EDTA}^{4}=\mathrm{ZrEDTA} \quad \log \mathrm{K}_{\mu=0 @ 25^{\circ} \mathrm{C}}=32.9
\end{aligned}
$$

The influence of major ions on the aqueous phase speciation of $\mathrm{Am}, \mathrm{Cs}, \mathrm{Ni}, \mathrm{NpO}_{2}, \mathrm{Pd}$, $\mathrm{PuO}_{2}, \mathrm{Rb}, \mathrm{Sr}, \mathrm{UO}_{2}$, and $\mathrm{Zr}$ were included in this analysis. OM forms complexes with 
major ions (e.g., $\mathrm{Al}^{3+}$ and $\mathrm{Fe}^{3+}$ ) found in mineral phases in soils and sediments at the SRS site. The major mineral phases were assumed to be kaolinite and geothite (Johnson, 1994). The competitive effects from major ions were considered by incorporating the major mineral phases of the system into the model and were assumed to have an infinite supply in this system.

In the model, radionuclides were allowed to sorb to soil surfaces to the extent predicted by the baseline $\mathrm{K}_{d}$ values. Any nuclide complexed by $\mathrm{OM}$, however, was unable to sorb to soil surfaces. Using this approach, a new effective $\mathrm{K}_{d}$, accounting for the presence of DOM was calculated from the output of the MINTEQA2 geochemical model. These new $\mathrm{K}_{d}$ values probably represent a lower limit (i.e., correspond to maximum increased nuclide mobility) as this calculation does not account for the effects of degradation, sorption, or dilution of OM.

\section{Flow/Box modeling}

Because $O M$ is susceptible to dilution, degradation and sorption in the environment, the assumption that all OM is available to react in the system is very conservative. In order to remove some of the conservatism from the speciation model, a simple flow/box model, after Lasaga (1980), was applied to OM to account for these types of losses. It was assumed that only dilution, degradation, and sorption affected this system. The layout of the three box model system for this problem is presented in Figure 1 .

The following losses were assumed at each step (box) along the flow path:

1. Dilution accounted for $19 \%$, based on groundwater flow modeling after $\mathrm{Yu}$ and Lam, 1994;

2. Degradation from the system accounted for $34 \%$, based on degradation of organic matter in a surface water aquatic system (Thurman, 1985); and

3. Sorption accounted for $20 \%$ (Murphy et.al., 1990).

\section{Recalculate $K_{d}$ and radionuclide inventory limits}

Due to the ubiquitous nature of $\mathrm{OM}$ in the environment, it was assumed that original $\mathrm{K}_{d}$ values accounted for $0.5 \mathrm{mg} \mathrm{C} / \mathrm{L}$ of naturally occurring $\mathrm{OM}$. This concentration is onehalf of the commonly accepted method detection limit for total organic carbon.

For the purposes of calculating new effective $\mathrm{K}_{d}$ values in the presence of $\mathrm{OM}$, the system was split into two regions:

1. Where $\mathrm{OM}<0.5 \mathrm{mg} \mathrm{C} / \mathrm{L}$ and the standard $\mathrm{K}_{d}$ values applied (i.e., no effect from DOM); and

2. Where $\mathrm{OM} \geq 0.5 \mathrm{mg} \mathrm{C} / \mathrm{L}$ and new $\mathrm{K}_{d}$ values were calculated to account for the additive effect of OM. For simplicity, a simple arithmetic average DOM concentration (15 mg $\mathrm{C} / \mathrm{L}$ ) was used for speciation modeling of this region. 
A new effective $\mathrm{K}_{d}$ for the system was calculated using a weighted average of the $\mathrm{K}_{d}$ values from each region. Using a simple ratio between the new effective $\mathrm{K}_{d}$, the $\mathrm{PA} \mathrm{K}_{d}$, and the PA soil trench inventory limit, new inventory limits were calculated using the following equation.

$$
\text { Adjusted Inventory }=P A \text { Inventory } x \frac{K_{d}(\text { new })}{K_{d}(\text { old })}
$$

A lower boundary on the applicability of these calculations in terms of percentage wood products in the waste stream was also estimated. This was accomplished by plotting the experimental data of Serne et al.(1993), and graphically estimating the percentage of wood products associated with the no effect from DOM level $(0.5 \mathrm{mg} \mathrm{C} / \mathrm{L})$.

\section{RESULTS}

\section{Base Case}

The results of modeling the base scenario are presented in Figure 2. The $\mathrm{K}_{d}$ values are linear for $\mathrm{Cs}, \mathrm{Ni}, \mathrm{NpO}_{2}, \mathrm{Pd}, \mathrm{Rb}$ and $\mathrm{Sr}$. The $\mathrm{K}_{d}$ values for $\mathrm{Am}, \mathrm{PuO}_{2}, \mathrm{UO}_{2}$, and $\mathrm{Zr}$ decrease with increasing $\mathrm{pH}$. This decrease in $\mathrm{K}_{d}$ values with increasing $\mathrm{pH}$ is an artifact of the modeling process. The formation of hydroxyl compounds with these components causes an apparent increase in the solubility of the components. However, these hydroxyl compounds are highly susceptible to adsorption on to mineral surfaces. The speciation modeling did not account for the adsorption of these compounds.

\section{Effects of Organic Matter}

The results of modeling the base case with the addition of citrate $(79 \mathrm{mg} / \mathrm{L}$ ) or EDTA (69 $\mathrm{mg} / \mathrm{L}$ ) are presented in Figures 3 and 4, respectively. The $\mathrm{K}_{d}$ values for $\mathrm{Cs}, \mathrm{Rb}$ and $\mathrm{Zr}$ are linear, and are unchanged by the addition of citrate or EDTA to the system. The decrease in $\mathrm{K}_{d}$ values for $\mathrm{Am}, \mathrm{Ni}, \mathrm{NpO}_{2}, \mathrm{Pd}, \mathrm{PuO}_{2}, \mathrm{Sr}$, and $\mathrm{UO}_{2}$ range from one order of magnitude for $\mathrm{Pd}$ to five orders of magnitude for $\mathrm{Am}$. The decrease in $\mathrm{K}_{d}$ values of $\mathrm{Am}, \mathrm{Ni}, \mathrm{NpO}$, $\mathrm{Pd}, \mathrm{PuO} 2, \mathrm{Sr}$, and $\mathrm{UO}_{2}$ with increasing $\mathrm{pH}$ are a result of the increase in the availability of DOM binding sites that were previously occupied by $\mathrm{H}^{+}$.

\section{Flow/Box Modeling}

The results of the flow/box modeling are presented in Figure 5. Citrate concentration remains above $1.3 \mathrm{mg} / \mathrm{L}(0.5 \mathrm{mg} \mathrm{C} / \mathrm{L})$ in groundwater for approximately 74 meters.

\section{Recalculate $K_{d}$ and Radionuclide Inventory Limits}

The recalculated $\mathrm{K}_{d}$ values and associated inventory limits are presented in Table 1 . In MMES, 1994, it was assumed that distribution coefficients for $\mathrm{Bk}, \mathrm{Cm}$, and $\mathrm{Cf}$ were the 
same as $\mathrm{Am}$. In order to recalculate the inventory limits for $\mathrm{Bk}, \mathrm{Cm}$, and $\mathrm{Cf}$, it was assumed that their behavior in the presence of OM would be analogous to Am.

The results of determining a lower boundary on the effect of OM is presented in Figure 6. A level of $1.5 \%$ wood products is associated with the no effect from DOM (i.e., DOM concentrations less than $0.5 \mathrm{mg} \mathrm{C} / \mathrm{L}$ ).

\section{CONCLUSIONS}

The adjusted inventory limits contained in Table 1 reflect the effects of the addition of OM (30 mg C/L) to the source term. Results of this modeling effort may be useful in estimating appropriate disposal levels of wood products, including railroad ties, in the EArea slit trenches. The OM was assumed to only affect those radionuclides with a groundwater limiting pathway.

The $30 \mathrm{mg} \mathrm{C} / \mathrm{L}$ source term used in this modeling effort is consistent with laboratory batch leaching studies of Serne et al. (1993), that considered a waste derived from homogeneously mixed simulated solid-waste forms, including approximately $40 \%$ wood products by weight. In order to apply these modeling results to disposal of wastes in the E-Area slit trenches, efforts should be made to insure that wood products are homogeneously mixed and do not exceed $40 \%$ by weight of wastes disposed of in the active disposal area of the slit trench. These operational criteria will most closely match the laboratory conditions of Serne et.al. (1993), which was the basis for the source term. Disposal of wood products in any area of the slit trench in concentrations greater than $40 \%$ by weight could result in higher concentrations of OM and increased mobility of radionuclides (i.e., lower inventory limits) than predicted by this modeling effort.

Extrapolating from the results of Serne et al. (1993), a measurable concentration of OM ( $0.5 \mathrm{mg} \mathrm{C} / \mathrm{L}$ ) was estimated for wood products levels $\geq 1.5 \%$ by weight. Therefore, it could be assumed that no effects from wood products would be expected at wood product levels lower than $1.5 \%$ by weight.

\section{UNCERTAINTIES}

The degradation rates of wood products and railroad ties and the nature of the degradation products are not well characterized. These uncertainties require that many conservative assumptions be applied to this activity. This is especially true of the estimation of the lower boundary of wood product disposal. This estimation was based on extrapolation from a limited number of data points. Additional laboratory leaching studies, simulating this waste and site specific leaching conditions would provide data to revise the assumptions applied to this activity. 


\section{REFERENCES}

Allison, J.D., Brown, D.S. and Gradac, K.J. (1991). MINTEQA2/PRODEFA2: A Geochemical Assessment Model for Environmental Systems: Version 3.0 Users Manual. U.S. Environmental Protection Agency, EPA/600/3-91/021.

Baston, G.M.N., Berry, J.A., Bond, K.A., Brownsword, M., and Linklater, C.M. (1992). Effects of Organic Degradation Products on the Sorption of Actnides. Radiochimica Acta, Vol. 58-59, 349-356.

Cozzarelli, I.M., Baedecker, M.J., Eganhouse, R.P., Goerlitz, D.F. (1994). The Geochemical Evolution Of Low-Mocular-Weight Organic Acids Derived From The Degradation Of Petroleum Contaminants In Groundwater. Geochimica et Cosmochimica Acta, Vol. 58, 863-877.

Johnson, N.A. (1994). Clay mineralogy of the surficial aquifer and confing system, F- and H-Area Seepage Basins, Savannah River Site. Phase 1 - Final report. University of Florida, Dept. of Geology.

Katz, J.J., Seaborg, G.T., and Morss, L.R. (1986). The Chemistry of Actinide Elements, Volume 1. Chapman and Hall, New York.

Lasaga, A.C.(1980). The Kinetic Treatment of Geochemical Cycles. Geochimica et Cosmochimica Acta, vol. 44, 815-828.

Martell, A.E. and Smith, R.M. (1989). Critical Stability Constants, Volume 3: Other Organic Ligands. Plenum Press, New York.

MMES (Martin marietta Energy systems), EG\&G Idaho, Inc., and Westinghouse Savannah River Company, (1994). Radiological Assessment for the E-area Vaults Disposal Facility (U). Report No. WSRD-RP-94-218, Rev. 0. WSRC, Aiken, SC.

Murphy, E.M., Zachara, J.M. and Smith, S.C. (1990). Influence of Mineral-Bound Humic Substances on the Sorption of Hydrophobic Organic Compounds. Environ. Sci. Technol., Vol.24, 1507-1516.

Perdue, E.M. and Gjessing, E.T. (1990). Dahlem Workshop Reports: Organic Acids in Aquatic Ecosystems. Wiley \& Sons, New York.

Rizkalla, E.N., Nectoux, F., Dabos-Seignon, S., and Pages, M. (1990). Complexation of Neptunium(V) by Halo- and Hydroxycarboxylate Ligands. Radiochimica Acta, Vol. 51. 113-117. 


\section{REFERENCES (cont.)}

Serne, R.J., Conca, J.L., LeGora, V.L., Cantrell, K.J., Lindenmeier, C.W., Campbell, J.A., Amonette, J.E. and Wood, M.I. (1993). Solid-Waste Leach Characteristics and Contaminant-Sediment Interactions, Volume 1: Batch Leach and Adsorption Tests and Sediment Characterization. Report No. PNL-8889 Vol. 1. PNL, Richland, WA.

Stumm W. and Morgan, J.J. (1981). Aquatic Chemistry. Wiley \& Sons, New York.

Strom, R.N. and Kaback, D.S. (1992). SRP baseline hydrogeologic investigation: Aquifer characterization. Groundwater geochemistry of the Savannah River Site and vicintiy. Report No. WSRC-RP-92-450. WSRC, Aiken, SC.

Thurman, E.M. (1985). Organic Geochemistry of Natural Waters. Kluwer Academic, Hingham, MA.

Yu, A.D. and Lam, P.S. (1994). Simulation of Radionuclide Migration in the Groundwater fro the Proposed Disposal of naval Reactor Casks in the E-Area. Report No. WSRC-RP-94-772. WSRC, Aiken, SC. 


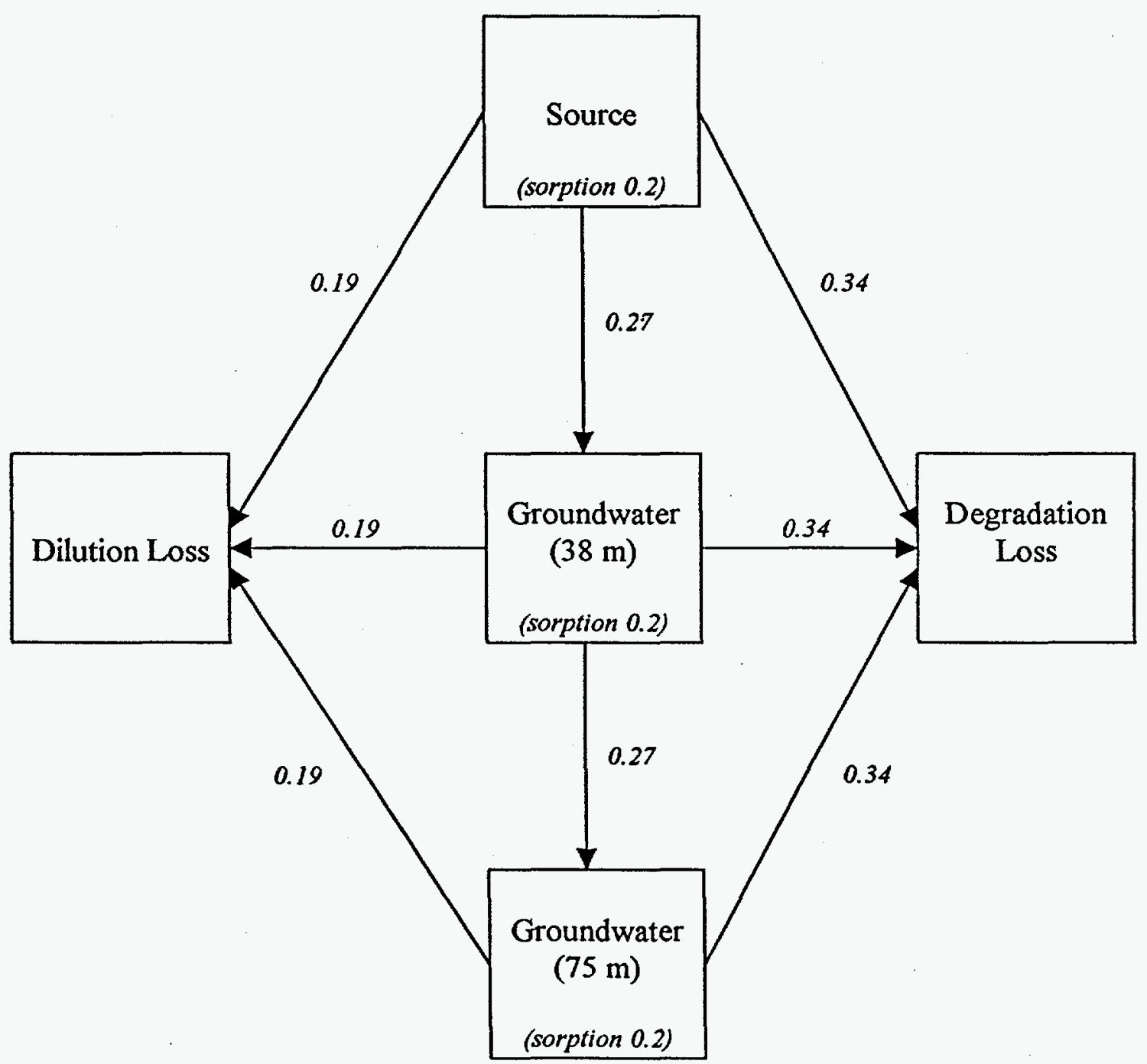

Figure 1. Box model for citrate in groundwater system note: italicized numbers represent fluxes between pools 


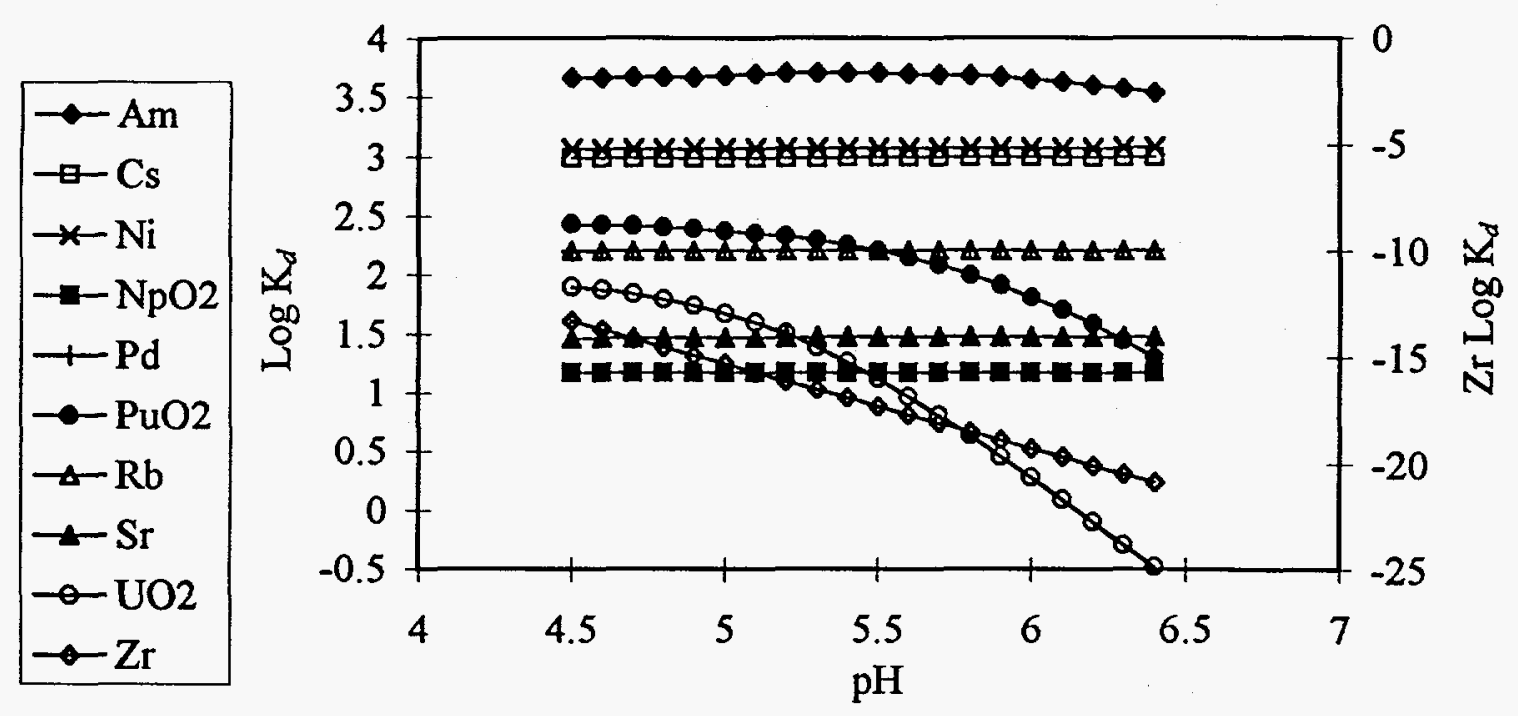

Figure 2. Sorption for system without $\mathrm{OM}$

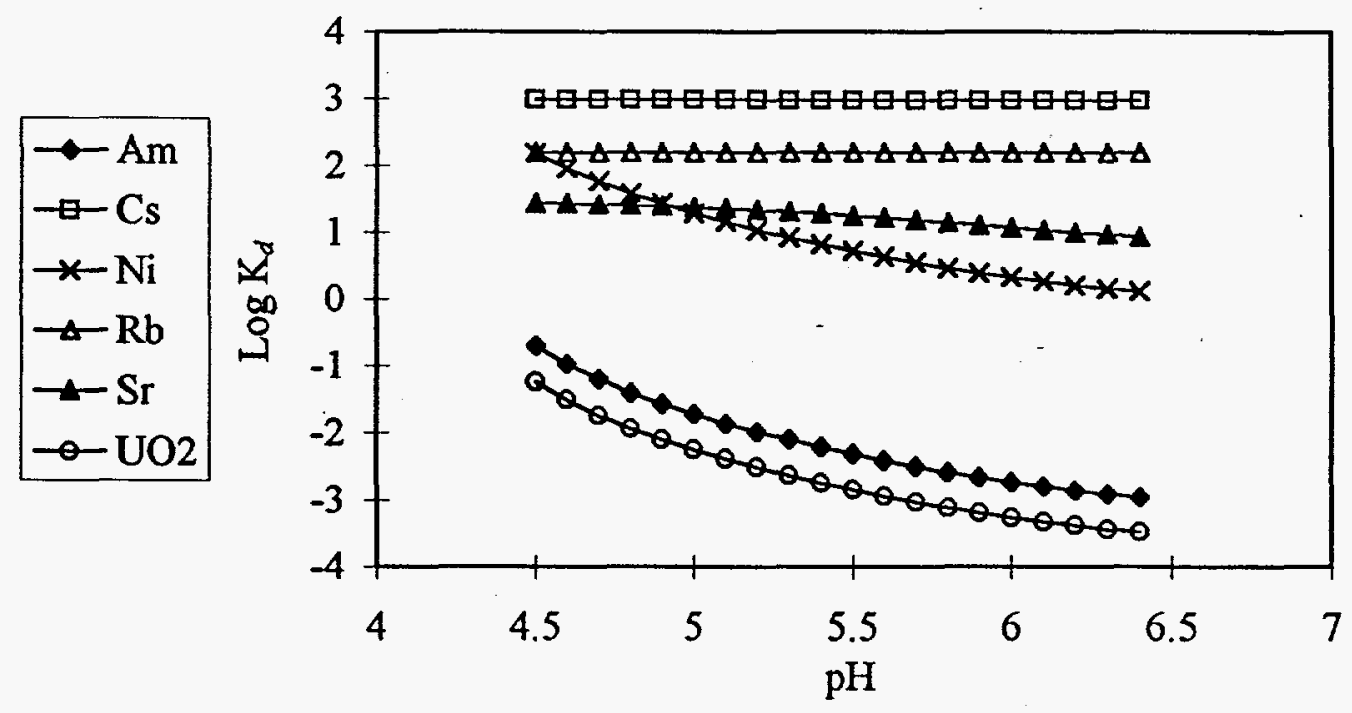

Figure 3. Sorption for system with $79 \mathrm{mg} / \mathrm{L}$ Citrate $(30 \mathrm{mg} \mathrm{C} / \mathrm{L})$ 


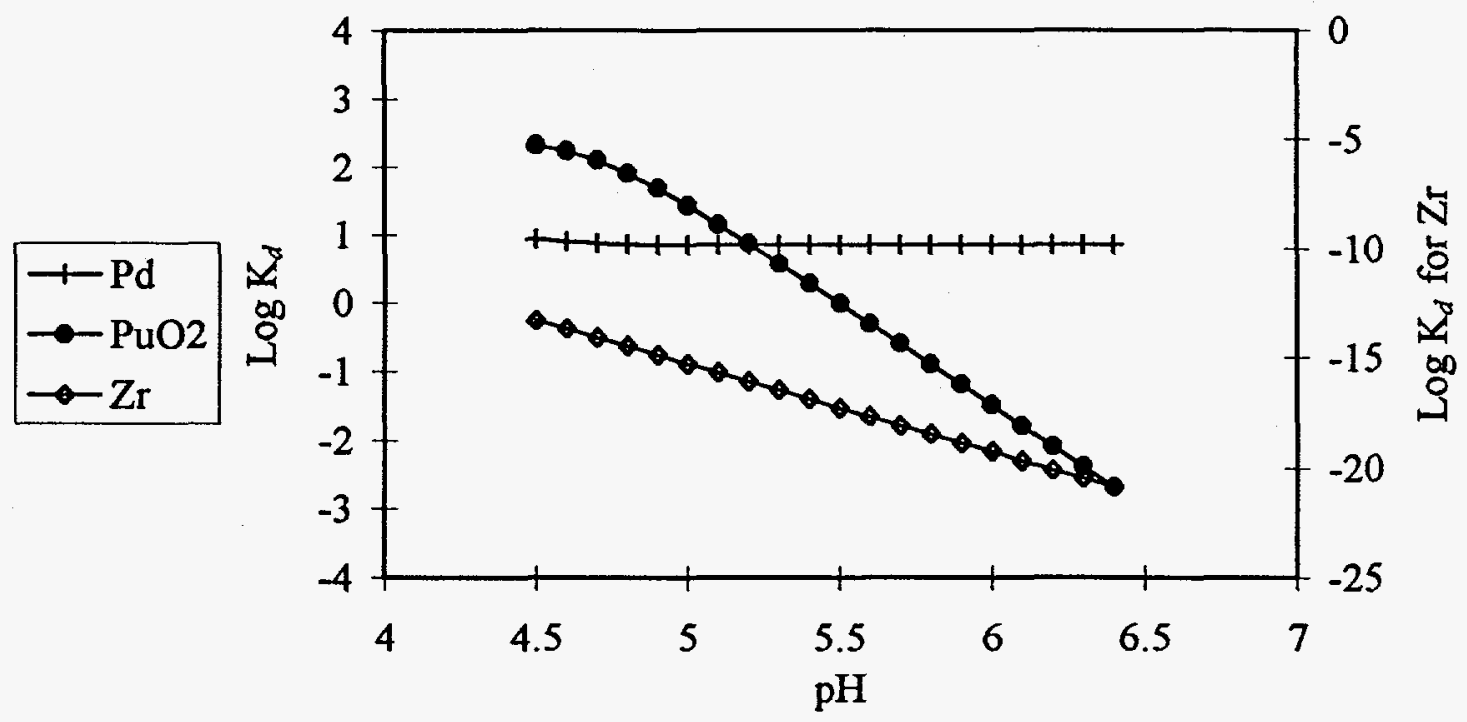

Figure 4. Sorption for system with $69 \mathrm{mg} / \mathrm{L}$ EDTA (30 mg

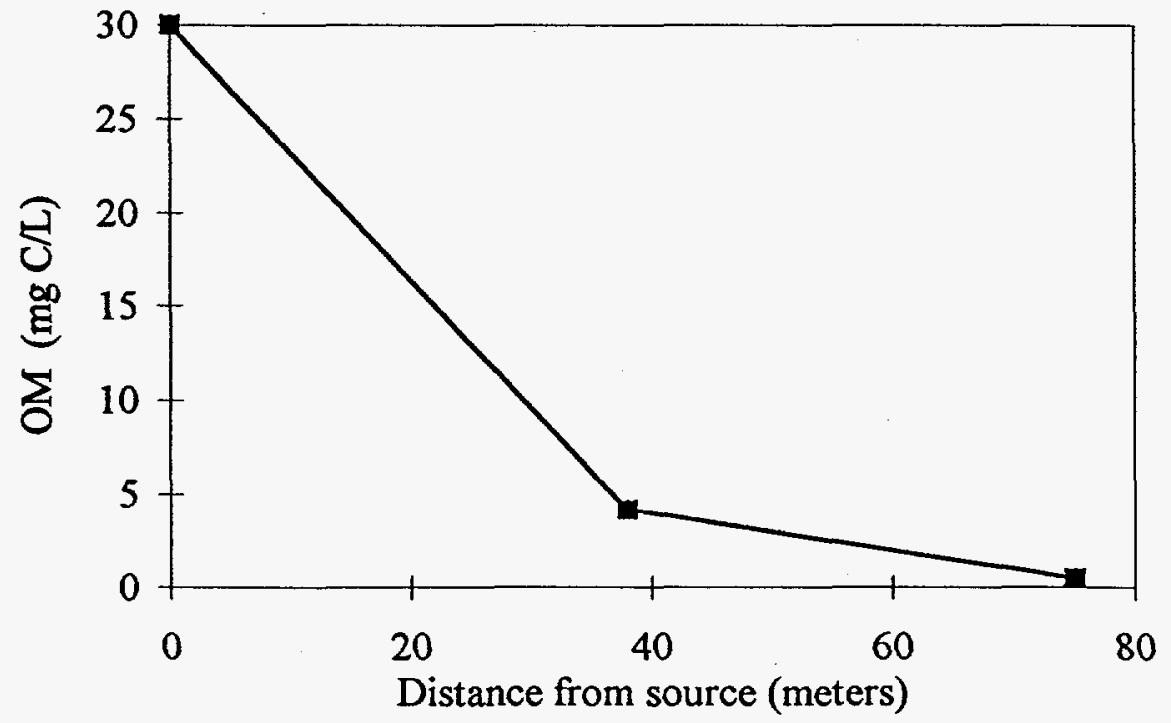

Figure 5. OM concentration predicted by flow/box modeling. 


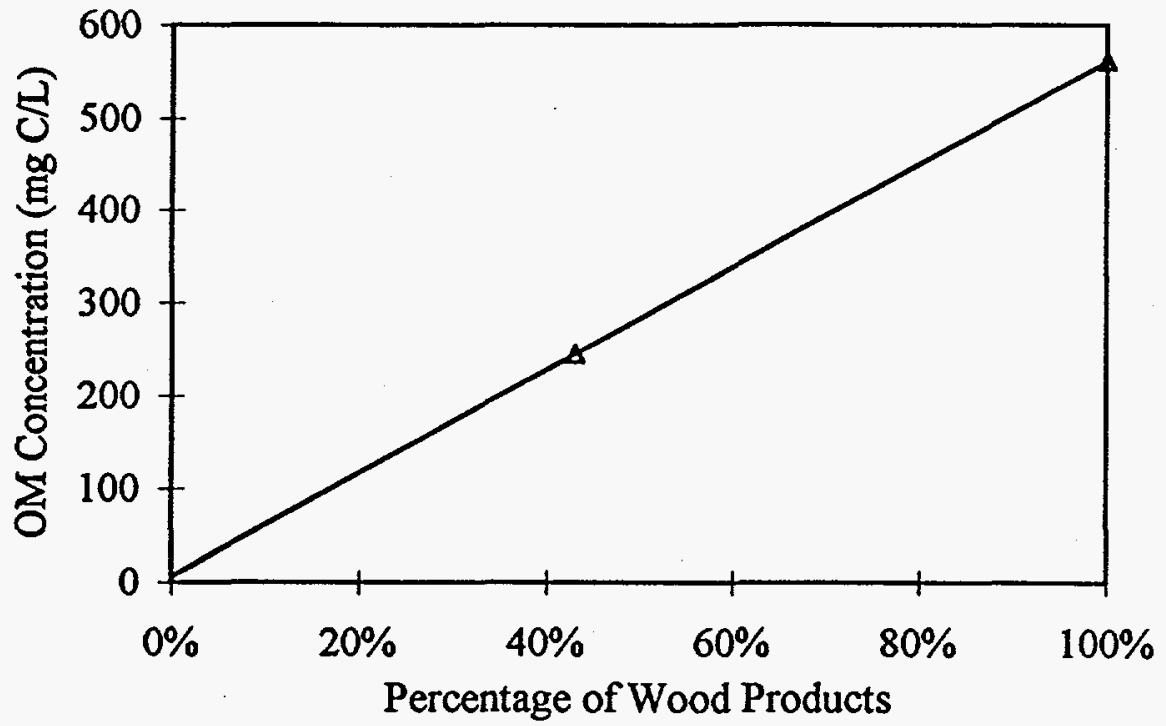

Figure 6. Relationship between Wood products and OM concentration. (Data from Serne et al., 1993) 
Table 1. Suspect Soil Trench Inventory Limits, adjusted for $30 \mathrm{mg} \mathrm{C} / \mathrm{L}$ at the source area.

\begin{tabular}{|c|c|c|c|}
\hline Radionuclide & Limiting Pathway & $\begin{array}{l}\text { Suspect Soil Trench } \\
\text { Inventory Limits }^{a} \\
\text { (Ci) } \\
\end{array}$ & $\begin{array}{c}\text { Adjusted Suspect Soil Trench } \\
\text { Inventory Limits } \\
\text { (Ci) }\end{array}$ \\
\hline $\mathrm{H}-3$ & \begin{tabular}{|l|} 
Groundwater \\
\end{tabular} & $1.1 \mathrm{E}+01$ & $1.1 \mathrm{E}+01^{\mathrm{no}}$ \\
\hline $\mathrm{C}-14$ & Groundwater & $2.0 \mathrm{E}+01$ & $2.0 \mathrm{E}+01^{\mathrm{po}}$ \\
\hline Al-26 & Intruder & 1.2 & $1.2^{\mathrm{nc}}$ \\
\hline Co-60 & Intruder & $6.2 \mathrm{E}+05$ & $6.2 \mathrm{E}+05^{\mathrm{nc}}$ \\
\hline $\mathrm{Ni}-59$ & Groundwater & $2.8 \mathrm{E}+03$ & $1.0 \mathrm{E}+03$ \\
\hline $\mathrm{Ni}-63$ & Intruder & $5.3 \mathrm{E}+04$ & $5.3 \mathrm{E}+04^{\mathrm{nc}}$ \\
\hline Se-79 & Groundwater & 7.2 & $7.2^{\mathrm{ne}}$ \\
\hline $\mathrm{Rb}-87$ & Groundwater & $2.9 \mathrm{E}+01$ & $2.9 \mathrm{E}+01$ \\
\hline Sr -90 & Groundwater & $3.1 E+02$ & $2.8 \mathrm{E}+02$ \\
\hline $\mathrm{Zr}-93$ & Groundwater & $6.4 \mathrm{E}+04$ & $6.4 \mathrm{E}+04$ \\
\hline $\mathrm{Nb}-93 \mathrm{~m}$ & Intruder & $2.6 \mathrm{E}+07$ & $2.6 \mathrm{E}+07^{\mathrm{nc}}$ \\
\hline Tc-99 & Groundwater & 9.1E-01 & $9.1 \mathrm{E}-01^{\mathrm{no}}$ \\
\hline Pd-107 & Groundwater & $3.7 \mathrm{E}+03$ & $1.2 \mathrm{E}+03$ \\
\hline $\mathrm{Cd}-113 \mathrm{~m}$ & Intruder & $5.3 E+03$ & $5.3 \mathrm{E}+03^{\mathrm{no}}$ \\
\hline Sn121m & Intruder & $3.3 E+04$ & $3.3 \mathrm{E}+04^{\mathrm{nc}}$ \\
\hline Sn-126 & Intruder & 2.1 & $2.1^{\mathrm{nc}}$ \\
\hline I-129 & Groundwater & $6.6 \mathrm{E}-04$ & $6.6 \mathrm{E}-04^{\mathrm{nc}}$ \\
\hline Cs-135 & Groundwater & $1.8 \mathrm{E}+03$ & $1.8 \mathrm{E}+03$ \\
\hline Cs-137 & Intruder & $5.6 \mathrm{E}+01$ & $5.6 \mathrm{E}+01^{\mathrm{nc}}$ \\
\hline Sm-151 & Intruder & $9.4 \mathrm{E}+05$ & $9.4 \mathrm{E}+05^{\mathrm{nc}}$ \\
\hline Eu-154 & Intruder & $6.7 \mathrm{E}+03$ & $6.7 \mathrm{E}+03^{\mathrm{nc}}$ \\
\hline Eu-155 & Intruder & $1.3 \mathrm{E}+08$ & $1.3 \mathrm{E}+08^{\mathrm{nc}}$ \\
\hline $\mathrm{Pb}-210$ & Intruder & $3.3 \mathrm{E}+02$ & $3.3 \mathrm{E}+02^{\mathrm{ne}}$ \\
\hline $\mathrm{Ra}-226$ & Intruder & $4.2 \mathrm{E}-02^{b} / 1.9^{c}$ & $\left(4.2 \mathrm{E}-02^{b} / 1.9^{c}\right)^{n c}$ \\
\hline Th-229 & Intruder & $1.1 \mathrm{E}+01$ & $1.1 \mathrm{E}+01^{\mathrm{nc}}$ \\
\hline Th-230 & Intruder & $4.1 \mathrm{E}+02$ & $4.1 \mathrm{E}+02^{\mathrm{nc}}$ \\
\hline Th-232 & Intruder & $3.2 \mathrm{E}-01^{b} / 1.3^{c}$ & $\left(3.2 \mathrm{E}-01^{b} / 1.3^{c}\right)^{n c}$ \\
\hline $\mathrm{Pa}-231$ & Intruder & 5.8 & $5.8^{\mathrm{nc}}$ \\
\hline $\mathrm{U}-232$ & Intruder & $1.4^{b} / 7.5^{c}$ & $\left(1.4^{b} / 7.5^{c}\right)^{n c}$ \\
\hline U-233 & Groundwater & 8.9 & 2.3 \\
\hline U-234 & Groundwater & 9.4 & 2.5 \\
\hline
\end{tabular}


Table 1. (continued)

\begin{tabular}{|c|c|c|c|}
\hline Radionuclide & Limiting Pathway & $\begin{array}{l}\text { Suspect Soil Trench } \\
\text { Inventory Limits } \\
\text { (Ci) }\end{array}$ & $\begin{array}{c}\text { Adjusted Suspect Soil Trench } \\
\text { Inventory Limits } \\
\text { (Ci) }\end{array}$ \\
\hline $\mathrm{U}-235$ & Groundwater & 3.1 & $8.1 \mathrm{E}-01$ \\
\hline $\mathrm{U}-236$ & Groundwater & 9.9 & 2.6 \\
\hline $\mathrm{U}-238$ & Groundwater & $4.8 \mathrm{E}-01$ & $1.3 \mathrm{E}-01$ \\
\hline $\mathrm{Np}-237$ & Groundwater & $1.1 \mathrm{E}-01$ & $1.1 \mathrm{E}-01$ \\
\hline $\mathrm{Pu}-238$ & Intruder & $3.5 E+02$ & $3.5 E+02^{n c}$ \\
\hline Pu-239 & Groundwater & 1.9 & $9.1 \mathrm{E}-01$ \\
\hline $\mathrm{Pu}-240$ & Groundwater & 3.1 & 1.5 \\
\hline Pu-241 & Intruder & $2.9 \mathrm{E}+03$ & $2.9 \mathrm{E}+03^{\mathrm{nc}}$ \\
\hline $\mathrm{Pu}-242$ & Groundwater & 1.7 & $8.1 \mathrm{E}-01$ \\
\hline Pu-244 & Groundwater & 1.7 & $8.1 \mathrm{E}-01$ \\
\hline Am-241 & Intruder & $9.6 \mathrm{E}+01$ & $9.6 \mathrm{E}+01^{\mathrm{nc}}$ \\
\hline Am-242m & Intruder & $8.8 \mathrm{E}+01$ & $8.8 \mathrm{E}+01^{\mathrm{nc}}$ \\
\hline Am-243 & Intruder/Ground & $1.8 \mathrm{E}+01$ & 4.7 \\
\hline $\mathrm{Cm}-242$ & Groundwater & $2.2 \mathrm{E}+08$ & $5.7 \mathrm{E}+07$ \\
\hline $\mathrm{Cm}-243$ & Intruder & $3.3 \mathrm{E}+02$ & $3.3 \mathrm{E}+02^{\mathrm{nc}}$ \\
\hline $\mathrm{Cm}-244$ & Groundwater & $1.1 \mathrm{E}+03$ & $2.9 \mathrm{E}+02$ \\
\hline $\mathrm{Cm}-245$ & Intruder & $5.1 \mathrm{E}+01$ & $5.1 \mathrm{E}+01^{\mathrm{nc}}$ \\
\hline $\mathrm{Cm}-246$ & Intruder & $1.4 \mathrm{E}+02$ & $1.4 \mathrm{E}+02^{\mathrm{nc}}$ \\
\hline $\mathrm{Cm}-247$ & Intruder & $1.2 \mathrm{E}+01$ & $1.2 \mathrm{E}+01^{\mathrm{nc}}$ \\
\hline $\mathrm{Cm}-248$ & Intruder & $3.9 \mathrm{E}+01$ & $3.9 \mathrm{E}+01^{1 \mathrm{NO}}$ \\
\hline Bk-249 & Groundwater & $1.0 \mathrm{E}+10$ & $2.6 \mathrm{E}+09$ \\
\hline Cf-249 & Intruder & $1.1 E+08$ & $1.1 \mathrm{E}+08^{\mathrm{nc}}$ \\
\hline Cf-250 & Groundwater & $6.90 \mathrm{E}+08$ & $1.8 \mathrm{E}+08$ \\
\hline Cf-251 & Intruder & $2.9 \mathrm{E}+01$ & $2.8 \mathrm{E}+01^{\mathrm{no}}$ \\
\hline Cf-252 & Groundwater & $1.4 \mathrm{E}+11$ & $3.6 \mathrm{E}+10$ \\
\hline
\end{tabular}

${ }^{a}$ Inventory Limits from MMES (1994). Limit on inventory in all five trenches; total volume of trenches is assumed to be $2.6 \times 10+4 \mathrm{~m} 3$

${ }^{b}$ Considers contribution to dose from radon decay procduct.

${ }^{c}$ Neglects contribution to dose from radon decay product.

* Inventory limits for as many of these radionuclides as possible will be incorporated into a future revision of this report.

${ }^{n}$ - Effect of Wood Products not expected to modify original limits. 